\title{
Perencanaan Arsitektur Perusahaan untuk Pengelolaan Aset di PT. Musdalifah Group menggunakan Kerangka Kerja Zachman
}

\author{
Indah Safarina $^{1)}$, Indra Kharisma Raharjana ${ }^{2)}$, Endah Purwanti ${ }^{3)}$ \\ ${ }^{122) 3)}$ Program Studi Sistem Informasi, Fakultas Sains dan Teknologi, Universitas Airlangga \\ Jalan Mulyorejo, Surabaya \\ 1)indah.safarina@gmail.com \\ 2)indra.kharisma@fst.unair.ac.id \\ 3)endah007@gmail.com
}

\begin{abstract}
Abstrak - Aset adalah hal penting yang dimiliki oleh setiap perusahaan atau organisasi. Proses manajemen aset yang dilakukan dengan tepat akan membuat aset yang dimiliki oleh perusahaan atau organisasi lebih optimal. Karena proses manajemen aset belum terlaksana dengan maksimal, maka pada penelitian ini direncanakan sebuah arsitektur enterprise untuk proses manajemen aset untuk kelompok perusahaan PT. Musdalifah Group dengan kerangka kerja Zachman melalui tujuh tahap. Tahap pertama adalah pengumpulan data terkait manajemen aset perusahaan yang digunakan sebagai acuan perencanaan. Tahap kedua adalah inisialisasi perencanaan yang menghasilkan rencana kerja arsitektur perusahaan sesuai ruang lingkup dan kondisi perusahaan. Tahap ketiga, meninjau kondisi enterprise saat ini perusahaan, dengan hasil tinjauan model proses bisnis dan katalog sumber daya perusahaan terkait manajemen aset. Tahap keempat adalah analisis hasil tinjauan enterprise dengan analisis SWOT, sehingga dapat dihasilkan 5 rencana proses bisnis serta usulan sistem dan teknologi terintegrasi. Tahap kelima melakukan perencanaan arsitektur enterprise yaitu arsitektur data dengan hasil 34 kandidat entitas data, arsitektur aplikasi yang menghasilkan 9 kandidat aplikasi, dan arsitektur teknologi dengan hasil 3 kandidat perangkat keras dan platform aplikasi yang terintegrasi. Sedangkan tahap terakhir, perencanaan implementasi hasil penelitian yaitu, rencana pemenuhan komponen, rencana migrasi, dan evaluasi dampak arsitektur. Evaluasi dari hasil penelitian menyatakan bahwa cetak biru arsitektur dapat diterima oleh perusahaan dan dipertimbangkan untuk diimplementasikan beberapa tahun kedepan.
\end{abstract}

Kata Kunci-Perencanaan Arsitektur Perusahaan, Kerangka Kerja Zachman, Manajemen Aset.

Abstract - Asset is an important thing that owned by any company or organization. Asset management process aims to manage an organization's assets optimally. Because of the asset management process has not been implemented maximally, so in this study planned an enterprise architecture for the process of asset management for the group of companies PT. Musdalifah Group using Zachman framework through seven phases. The first phase, data collection, and the results is relevant information of company's asset management as a design reference. The second phase, planning initialization, generates enterprise architecture work plan according to the scope and conditions of the company. The third phase, reviewing the company's current enterprise conditions, the results of the review are models of business processes and enterprise resource catalog of related asset management. The fourth phase, results review analysis of enterprise with SWOT analysis, so it can produce 5 plan and proposed business processes and technology systems terintegrasi. The fifth phase, enterprise architecture planning of data architecture with the results are 37 data entities candidates, application architecture which produces 9 applications candidate, and technology architecture with the results are 3 hardware and application platform candidates. The last phase, planning the implementation of the research's result, plan fulfillment component, the migration plan, and evaluating the impact of architecture. Evaluation of the result of research is describing that the architectural blueprints can be received by the company and considered to be implemented next few years.

Keywords — Enterprise Architecture Planning, Zachman Framework, Asset Management.

\section{PENDAHULUAN}

PT. Musdalifah Group sebagai perusahaan yang memiliki aset lancar berwujud di beberapa sub perusahaan, telah berkembang pesat dalam bidang bisnis barang perhiasan emas dan jasa penginapan hotel di Kabupaten Sumenep, sehingga dibutuhkan sebuah enterprise data, arsitektur dan teknologi yang baik serta 
terintegrasi untuk menangani proses manajemen aset tersebut. Selain itu, proses manajemen aset yang masih dilakukan menggunakan dokumen kertas, membuat dokumentasi dan pelaporan dari proses manajemen aset belum terintegrasi dan terealisasi dengan baik.

Aset yang bisa masuk dan keluar begitu saja dapat membuat manajer kewalahan ketika mengelola aset mulai dari perencanaan sampai penghapusan tanpa adanya sistem yang terintegrasi. Para pemilik, penyedia, atau operator aset dan infrastruktur juga dituntut untuk lebih sadar akan tantangan-tantangan dalam masyarakat zaman ini agar aset yang mereka kelola tidak menambah kerugian ataupun dampak negatif lain terhadap lingkungan dan masyarakat, terutama bagi perusahaan itu sendiri.

Manajemen Aset adalah cara dan ciri dalam mengatur, merencanakan, mendesain, dan memonitor dalam proses mengakuisisi, memelihara, memperbarui, dan pembuangan segala bentuk infrastruktur dan aset teknis, untuk mendukung pengadaan servis publik. Aset Manajemen adalah sesuatu yang sistematik, suatu proses yang terstruktur, mencakupi seluruh umur hidup suatu Aset fisik (Brown, et al., 2012).

Tujuan utama dari manajemen aset adalah membantu suatu organisasi dalam memenuhi tujuan penyediaan pelayanan secara efektif dan efisien (Hidayat, 2012). Sedangkan sasaran dari manajemen aset adalah untuk mencapai kecocokan atau kesesuaian sebaik mungkin antara aset dengan strategi penyediaan pelayanan.

Pengelolaan manajemen aset akan lebih efektif dan efisien apabila dilakukan dengan enterprise yang baik dengan sistem yang terintegerasi satu sama lain sehigga potensi pengadaan pelayanan dari aset lebih optimal, resiko dan biaya minimal, serta modal alami dan sosial dalam siklus kehidupan suatu aset meningkat. Perencanaan arsitektur enterprise akan mempengaruhi baiknya enterprise perusahaan.

Metode Perencanaan Arsitektur Enterprise (EAP) dalam Arsitektur Enterprise adalah sebuah proses perencanaan dan pendefinisian arsitektur dalam penggunaan informasi untuk mendukung kegiatan bisnis dan rencana pengimplementasian arsitektur itu sendiri. Mulai dari arsitektur data, aplikasi, sampai teknologi informasi atau sistem informasi (Minoli, 2008).

Penelitian perencanaan arsitektur enterprise (EAP) untuk proses manajamen aset telah dilakukan sebelumnya dengan studi kasus pada divisi manajemen fasilitas perusahaan PT. XYZ dengan menggunakan kerangka kerja Zachman yang menghasilkan cetak biru data, aplikasi, proses, dan teknologi sebagai acuan untuk sistem informasi manajemen aset dari PT. XYZ (Tyas \& Tarmuji, 2013). Penelitian lainnya tentang perencanaan arsitektur enterprise (EAP) untuk proses manajemen aset dengan kerangka kerja zachman juga telah dilakukan sebelumnya dengan studi kasus e-university pada Universitas Gajah Mada dengan menghasilkan cetak biru data, aplikasi, dan teknologi serta dokumen perancangan data, aplikasi, dan teknologi (Mahasanti, 2010). Penelitian untuk merancang sistem informasi manajemen aset pada PT. Ciptakridatama yang menghasilkan sebuah rancangan suatu sistem informasi untuk mengelola aset yang dimiliki meliputi permintaan aset, persetujuan, pembelian, register, pengiriman dan penerimaan aset telah dilakukan juga sebelumnya (Suhairi, 2013).

Hasil penelitian tersebut dapat dipertimbangkan dalam penelitian yang dilakukan terkait arsitektur enterprise manajemen aset pada kelompok perusahaan PT. Musdalifah Group. Perbedaan dari penelitian ini dengan penelitian sebelumnya yaitu pada perusahaan yang diteliti saat ini merupakan kelompok perusahaan yang terdiri dari 2 anak perusahaan dan belum melaksanakan proses manajemen aset dengan maksimal. Dari perbedaan tersebut, penelitian ini memiliki keterkaitan metode dan penggunaan kerangka kerja dari penelitian sebelumnya.

Untuk membantu dalam pencapaian tujuan yang diinginkan oleh PT. Musdalifah Group, maka akan direncanakan sebuah arsitektur enterprise proses manajemen aset meliputi kegiatan perencanaan, permintaan, perolehan, penggunaan, pemeliharaan, dan pelepasan aset dengan menggunakan kerangka kerja Zachman. Kerangka kerja Zachman merupakan suatu skema yang dapat digunakan untuk menganalisis dan membangun sebuah arsitektur enterprise dari suatu hal secara terstruktur (Zachman, 2003). Tujuannya agar efisiensi proses manajemen aset di perusahaan meningkat dengan menerapkan solusi data, aplikasi, dan teknologi yang tepat.

Hasil dari penelitian ini berupa cetak biru arsitektur data, aplikasi, dan teknologi yang dapat menjadi acuan pelaksanaan semua aktivitas manajemen aset PT. Musdalifah Group yang mencakup segala kebutuhan dari perusahaan sehingga manajemen aset dapat berjalan lebih efektif dan efisien.

\section{METODE PENELITIAN}

Penelitian ini mengadopsi tahapan model Birthday Cake seperti pada Gambar 1.

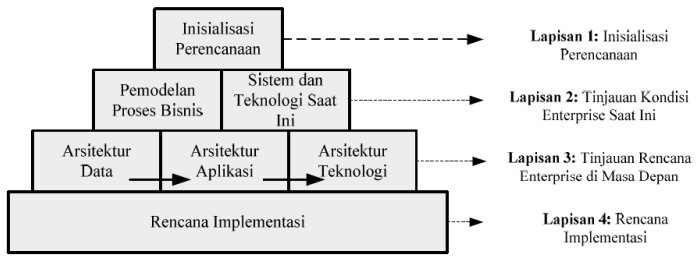

Gambar 1. Tahapan Perencanaan Arsitektur Enterprise (Spewak \& Hill, 1992) 
Tahapan pada penelitian ini disesuaikan dengan kerangka kerja Zachman yaitu dasar pemikiran untuk mengelompokkan dan mengorganisasikan representasi sebuah perusahaan yang penting bagi manajemen perusahaan dan pengembangan sistem selanjutnya. Kerangka kerja Zachman juga dapat diartikan sebagai skema yang dapat digunakan untuk menganalisis dan membangun sebuah arsitektur enterprise dari suatu hal (Zachman, 2003).

Kerangka kerja Zachman merupakan sebuah kerangka kerja untuk mengkategorikan arsitektur enteprise bukan suatu metodologi untuk mengembangkan arsitektur enterprise. Kerangka kerja Zachman dapat dimanfaatkan untuk menentukan apakah metodologi yang digunakan telah meliputi semua aspek dalam arsitektur enterprise atau aspek apa saja yang dicakup oleh metodologi.

Mengacu pada tahapan model birthday cake dan kerangka kerja zachman, tahapan pada penelitian ini dapat digambarkan dengan kerangka penelitian pada Gambar 2.

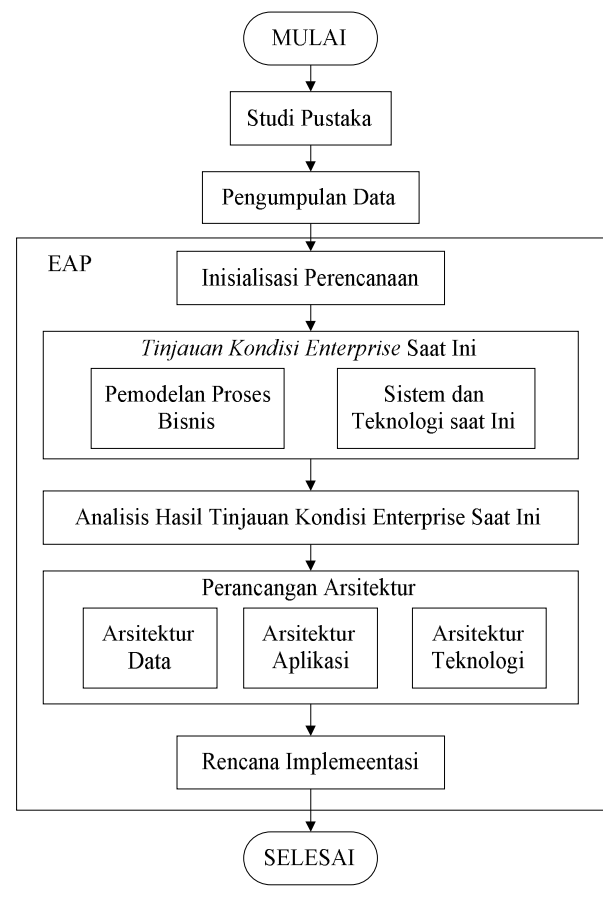

Gambar 2. Kerangka Penelitian

Tahapan-tahapan EAP pada penelitian ini dapat dijabarkan sebagai berikut:

\section{A. Inisialisasi perencanaan,}

Identifikasi tentang aturan-aturan yang menjadi rujukan di PT. Musdalifah Group terkait dengan perencanaan arsitektur enterprise pada proses manajemen aset.

\section{B. Tinjauan kondisi enterprise saat ini}

Dilakukan untuk menganalisis enterprise yang sedang berjalan di perusahaan.

\section{1) Pemodelan proses bisnis,}

Memetakan daftar proses bisnis yang berlaku saat ini di perusahaan, dan menggambarkannya dengan membuat model bisnis awal menggunakan Business Process Model sesuai dengan struktur organisasi.

\section{2) Sistem dan teknologi saat ini}

Pengidentifikasi dan pendokumentasian sistem dan teknologi yang digunakan pada enterprise saat ini dengan cara mengumpulkan data sistem dan teknologi yang sedang digunakan oleh PT. Musdalifah Group pada proses manajemen aset.

\section{Analisis hasil tinjauan kondisi enterprise saat ini}

Menganalisis kondisi enterprise dengan analisis SWOT dan meninjau kebutuhan perusahaan terhadap perubahan enterprise.

\section{Perancangan arsitektur}

Dilakukan untuk meninjau dan merencanakan enterprise yang cocok digunakan oleh perusahaan di masa depan sesuai dengan situasi dan kondisi perusahaan.

\section{1) Arsitektur data}

Mengidentifikasi dan merancang arsitektur data sesuai dengan kebutuhan entitas data dari prosesproses bisnis dan menggambarkan relasi antar entitas data pada Conceptual Data Model dan Physical Data Model.

\section{2) Arsitektur aplikasi}

Mengidentifikasi dan mendaftarkan kandidatkandidat aplikasi yang dapat digunakan selama proses bisnis berlangsung.

\section{3) Arsitektur teknologi}

Pendefinisian prinsip teknologi yang akan digunakan untuk menjalankan kandidat aplikasi yang sudah direncanakan.

\section{E. Rencana implementasi}

Merencanakan bagaimana arsitektur-arsitektur yang telah dirancang nantinya dapat digunakan oleh perusahaan.

\section{HASIL DAN PEMBAHASAN}

\section{A. Inisialisasi Perencanaan}

Hasil dari proses inisialisasi perencanaan yang dilakukan adalah sebagai berikut:

a) Rencana kerja EAP,

Didapatkan berdasarkan ruang lingkup EAP dan disesuaikan dengan metode perencanaan arsitektur enterprise pada lingkungan enterprise yang bejalan di PT. Musdalifah Group pada proses manajemen aset secara keseluruhan, yaitu: perencanaan aset, pengajuan aset, pengadaan aset, penerimaan 


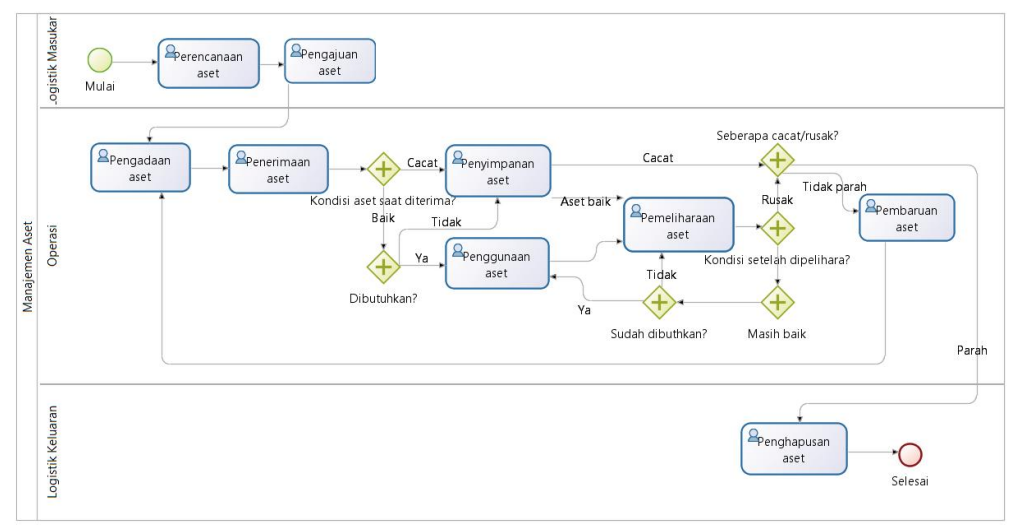

Gambar 3. Proses Manajemen Aset Keseluruhan

aset, penyimpanan aset, penggunaan aset, pemeliharaan aset, pembaruan aset, dan penghapusan aset sesuai dengan kerangka kerja Zachman mulai dari kolom data sampai kolom motivation dan baris objective/scope sampai baris motivationing enterprise.

b) Hasil analisis visi dan misi perusahaan,

Berdasarkan pada visi dan misi perusahaan poin ke-4 yaitu "terus melakukan peningkatan kualitas secara berkala pada empat pilar utama organisasi keuangan, aset, produk, dan tenaga kerja guna mencapai standardisasi perusahaan berbasis syariah Islam", penelitian yang dilakukan memiliki keterkaitan dengan visi dan misi perusahaan karena penelitian dapat menghasilkan cetak biru sarana prasarana perusahaan yang berkualitas sesuai kemajuan teknologi dengan enterprise terbaik dalam upaya pengoptimalan manajemen aset berbasis syariah dengan resiko dan biaya minimal tetapi maksimal pada pendapatan. Sehingga perusahaan berada di urutan pertama dalam perkembangan jejaring bisnis di Kabupaten Sumenep.

c) Penyesuaian metode penelitian.

Pendekatan metodologi EAP yang digunakan dalam pembuatan model konseptual arsitektur data, aplikasi, dan teknologi proses manajemen aset dengan berbasis pada kerangka kerja Zachman telah disesuaikan dengan enterprise yang ada saat ini di PT. Musdalifah Group, yaitu: inisialisasi perencanaan, pemodelan proses bisnis dan tinjauan sistem dan teknologi saat ini, perencanaan arsitektur data, aplikasi dan teknologi, serta rencana implementasi.

\section{B. Tinjauan Kondisi Enterprise Saat Ini}

\section{1) Pemodelan proses bisnis}

Unit organisasi yang berada dalam struktur organisasi memiliki tugas masing-masing terkait dengan proses manajemen aset di perusahaan. Proses bisnis manajemen aset secara umum dapat digambarkan dengan BPMN pada Gambar 3.
Proses bisnis manajemen aset perusahaan yang sedang berjalan saat ini adalah, sebagai berikut:

a) Perencanaan aset,

Proses perencanaan aset dilakukan atas pertimbangan kebutuhan aset perusahaan dan dilakukan pada saat bagian dari perusahaan membutuhkan aset dengan segera atau dibutuhkan sebagai stok gudang dengan mengisi formulir "purchase request". Proses perencanaan aset yang sedang berjalan saat ini dapat dilihat pada Gambar 4.

b) Pengajuan aset,

Proses pengajuan aset dilakukan ketika fromulir "purchase request" yang telah diisi diserahkan kepada ketua departemen untuk disetujui.

\section{c) Pengadaan aset,}

Pengadaan aset dilakukan ketika formulir "purchase request" telah disetujui dan diterima oleh bagian purchasing atau bagian penyimpanan aset dari duty manager.

\section{d) Penerimaan aset,}

Aset yang telah diadakan oleh bagian pengadaan yaitu purchasing dan gudang diserahkan kepada bagian penerima aset dari masing masing departemen.

e) Penyimpanan aset,

Penyimpanan aset di perusahaan PT. Musdalifah Group di laksanakan oleh 3 bagian penyimpnan yang berbeda. Dan bagian penyimpanan harus melakukan pengecekan terhadap aset secara berkala dengan mencocokkan aset yang sedang disimpan dengan kartu stok.

\section{f) Penggunaan aset,}

Penggunaan aset dilakukan setelah aset didistribusikan oleh bagian penerimaan aset dan bagian penyimpanan aset.

\section{g) Pemeliharaan aset,}

Pemeliharaan aset dilakukan di waktu tertentu pada aset yang digunakan oleh karyawan yang menggunakan. 


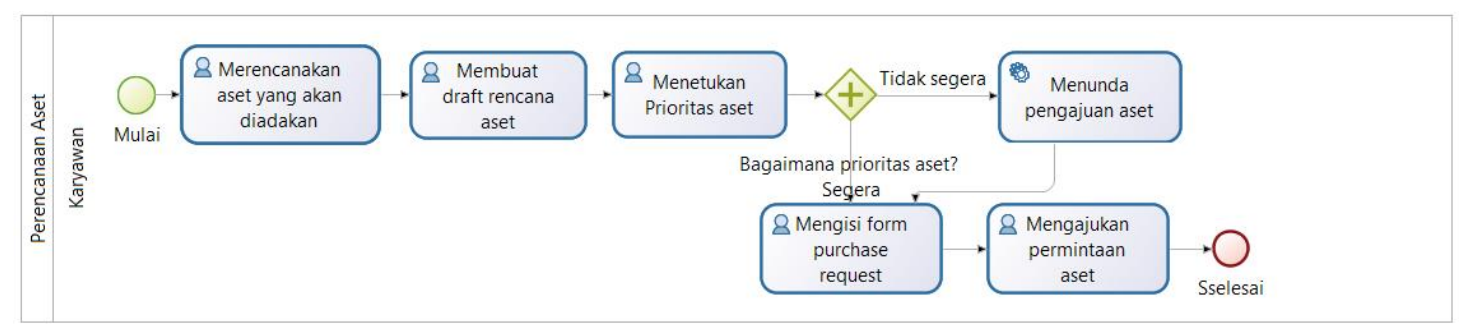

Gambar 4. Proses Perencanaan Aset

\section{h) Pembaruan aset,}

Pembaruan aset dilakukan apabila ada satu atau lebih karyawan yang mengajukan pembaruan aset atas aset yang rusak tetapi tidak parah yang dapat berupa penggantian aset atau perbaikan aset.

i) dan Penghapusan aset,

Penghapusan aset dilakukan pada akhir siklus manajemen aset apabila pengajuan penghapusan aset atas aset lama, atau aset rusak parah telah disetujui oleh ketua departemen, manajerial dan direksi.

\section{2) Sistem dan Teknologi Saat Ini}

Peninjauan terhadap sistem dan teknologi saat ini pada perusahaan terkait proses manajemen aset yang telah dilakukan menghasilkan pengetahuan bahwa perusahaan PT. Musdalifah Group masih menggunakan dokumen berupa kertas pada semua bagian sub perusahaannya. Komputer yang dimiliki oleh perusahaan hanya digunakan untuk kegiatan operasional saja.

Di Hotel Resort Musdalifah, proses manajemen aset dilakukan menggunakan dokumen-dokumen yang dapat menunjang kegiatan manajemen aset. Dokumen yang digunakan adalah formulir "purchase request" untuk perencanaan, pengajuan, dan pengadaan aset, formulir kartu stok untuk mencatat penerimaan dan pendistribusian aset, serta formulir "house keeping checklist" untuk mencatat kondisi aset saat proses pemeliharaan aset. Untuk kegiatan pengeluaran aset, pihak Hotel Resort Musdalifah masih menerapkan proses pelaporan secara lisan kepada bagian manajemen maupun direksi. Sedangkan sub perusahaan toko emas masih melakukan proses manajemen aset secara lisan.

\section{Analisis Hasil Tinjauan Kondisi Enterprise Saat Ini}

Berdasarkan hasil analisis SWOT (Tabel 1), proses bisnis manajemen aset yang saat ini sedang berjalan di perusahaan PT. Musdalifah memiliki lebih banyak kelemahan daripada kekuatan, serta lebih banyak ancaman daripada peluang.

Sedangkan sistem yang saat ini tersedia di perusahaan tidak dimanfaatkan secara optimal untuk proses manajemen aset. Sistem dan teknologi yang tersedia hanya digunakan untuk kegiatan operasional sehari-hari.

Dari hasil analisis tinjauan kondisi enterprise yang digunakan saat ini oleh perusahaan, telah direncanakan proses bisnis manajemen aset yang dapat dimanfaatkan bersama sistem dan teknologi yang teritegrasi dengan pendokumentasian yang baik. Gambar BPMN rencana proses bisnis secara umum dapat dilihat pada Gambar 5.

TABEL 1. HASIL ANALISIS SWOT

\begin{tabular}{|c|c|}
\hline SWOT & Analisis \\
\hline Strength & $\begin{array}{l}\text { - Bagian purchasing dari kedua sub } \\
\text { perusahaan terfiri dari satu unit yang sama } \\
\text { sehingga pengadaan aset menjadi terpusat } \\
\text { dan meminimalisir terjadinya kecurangan } \\
\text { yang biasanya timbul dari pihak vendor } \\
\text { - Adanya perangkat komputer yang dapat } \\
\text { dimanfaatkan untuk proses manajemen aset }\end{array}$ \\
\hline Weakness & $\begin{array}{l}\text { - Belum ada unit organisasi yang khusus } \\
\text { untuk menangani proses manajemen aset } \\
\text { terutama pada bagian maintenance } \\
\text { - Penggunaan dokumen dalam proses } \\
\text { pencatatan keluar masuknya aset kurang } \\
\text { baik karena tidak menjelaskan lokasi dan } \\
\text { siap penanggung jawab atas aset saat aset } \\
\text { didistribusikan } \\
\text { - Pelaporan terkait dengan kehidupan aset } \\
\text { kepada pihak organisasi bagian atas di } \\
\text { perusahaan belum teralisasi sehingga } \\
\text { manajer dan direktur mengambil keputusan } \\
\text { atas aset dari peninjauan secara langsung } \\
\text { - Tidak ada dokumen yang mencatat aset } \\
\text { yang digunakan pada lokasi tertentu setelah } \\
\text { aset didistribusikan } \\
\text { - Belum ada sistem yang menangani } \\
\text { penyimpanan data-data aset perusahaan } \\
\text { - Seringnya terjadi kerusakan dan } \\
\text { kehilangan aset perusahaan yang tidak } \\
\text { tercatat dengan baik } \\
\text { - Proses bisnis perusahaan terkait } \\
\text { manajemen aset masih kurang diperhatikan }\end{array}$ \\
\hline Opportunity & $\begin{array}{l}\text { - Letak perusahaan yang strategis sehingga } \\
\text { memudahkan pihak perusahaan untuk } \\
\text { mengembangkan aset } \\
\text { - Sedikitnya perusahaan swasta yang } \\
\text { menerapkan sistem kompuer terintegerasi } \\
\text { dalam proses manajemen aset }\end{array}$ \\
\hline Thread & $\begin{array}{l}\text { - Tidak tercapainya visi dan misi perusahaan } \\
\text { untuk menjadi pioneer perusahaan swasta } \\
\text { di Kabupaten Sumenep apabila proses } \\
\text { manajemen aset masih belum optimal } \\
\text { - Kualitas pengelolaan aset dapat } \\
\text { berpengaruh pada jumlah aset perusahaan } \\
\text { yang dapat tersaingi kapan saja oleh } \\
\text { perusahaan pesaing }\end{array}$ \\
\hline
\end{tabular}




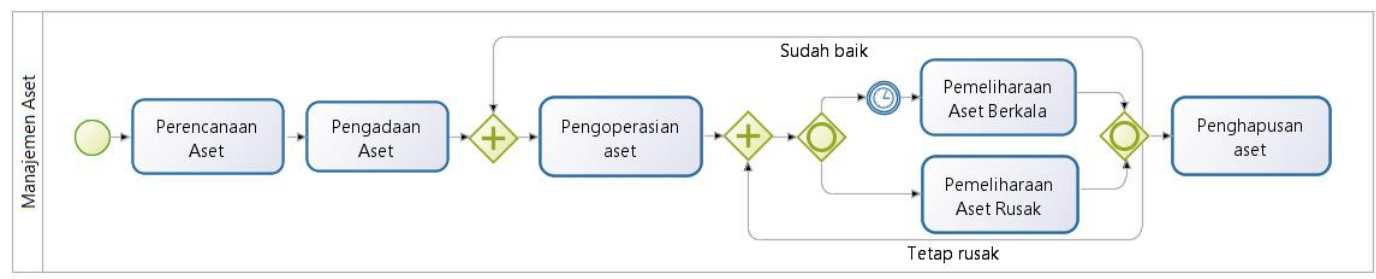

Gambar 5. Proses Bisnis Manajemen Aset Secara Umum

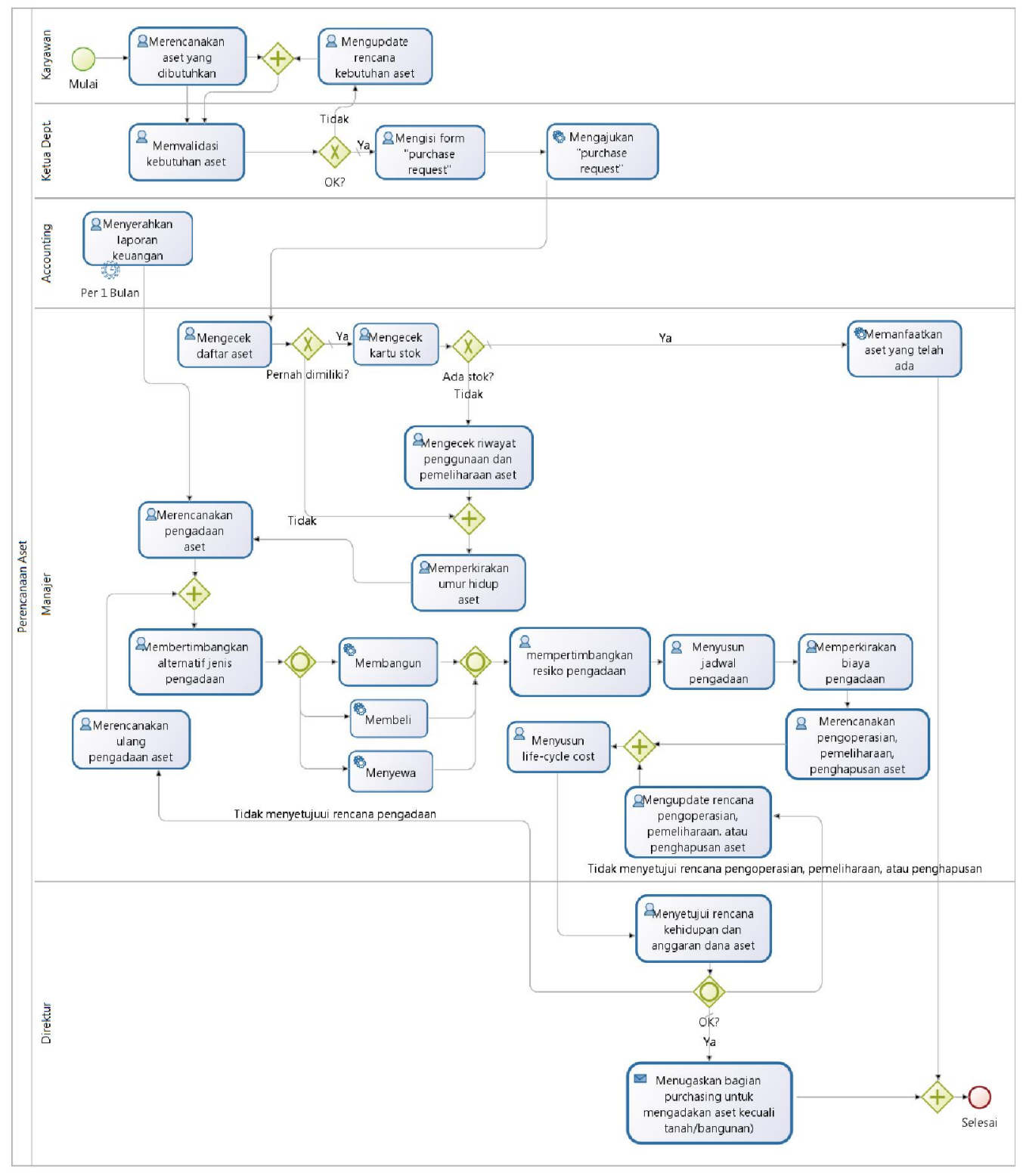

Gambar 6. Proses Bisnis Perencanaan Aset

Proses bisnis yang direncanakan terdiri dari 5 proses yaitu:

\section{a) Perencanaan aset,}

Proses perencanaan aset yang direncanakan memiliki prosedur yang lebih efektif daripada dari sisi pelaksana. Pada usulan ini tidak ada draft rencana aset, melainkan ketua departemen langsung mengisi "purchase request" setelah memperoleh keputusan hasil diskusi. Setelah itu, manajer mengecek stok aset pada sistem sebelum aset diadakan agar tidak terjadi penumpukan stok. BPMN perencanaan aset dapat dilihat pada Gambar 6.

\section{b) Pengadaan aset,}

Proses pengadaan aset yang direncanakan memiliki 2 kemungkinan pelaksana. Pengadaan aset dilakukan oleh bagian purchasing perusahaan setelah mendapatkan tugas dari bagian manajerial untuk mengadakan barang sesuai dengan formulir "purchase request" hanya untuk aset barang selain 


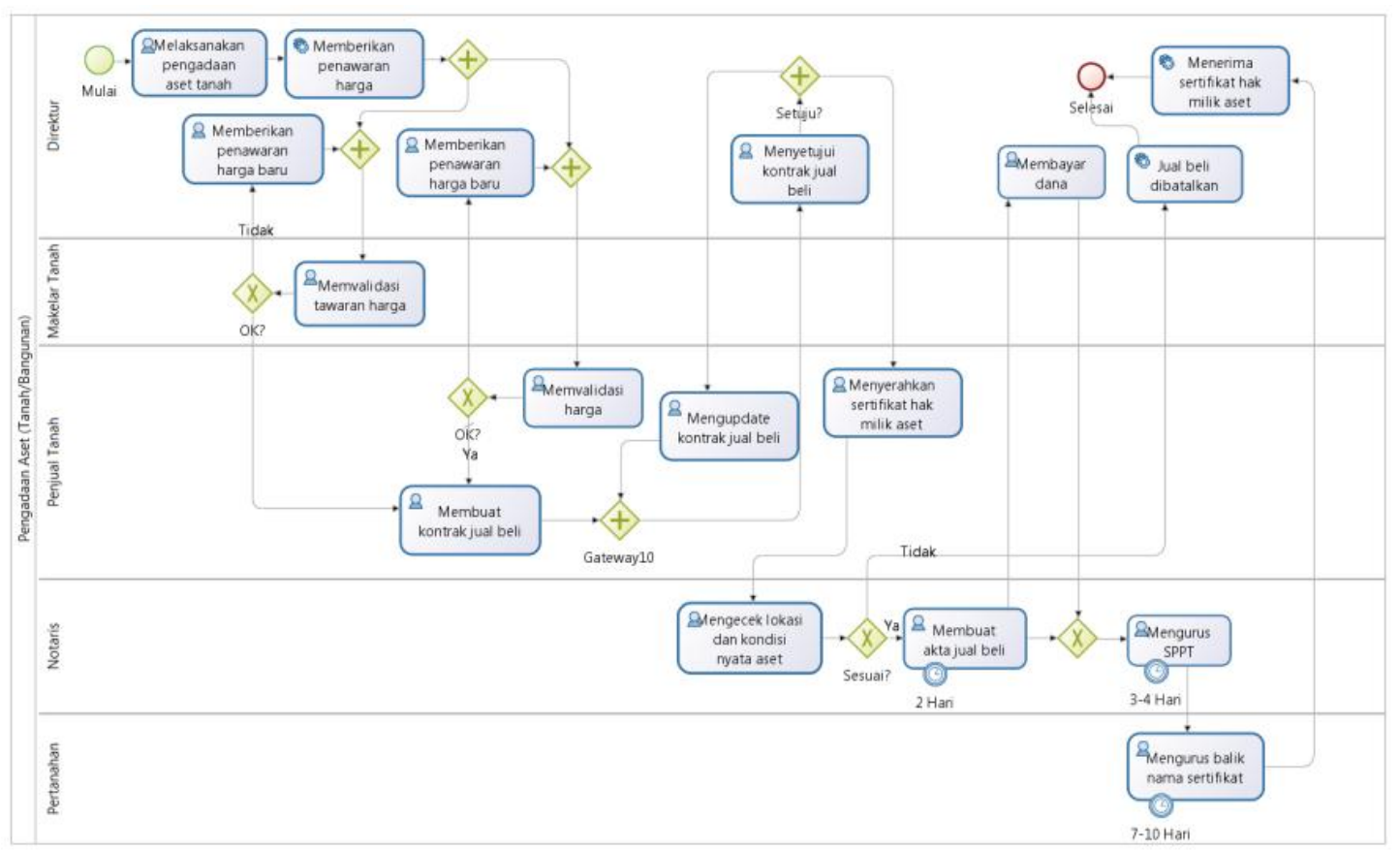

Gambar 7. Proses Pengadaan Aset Tanah dan Bangunan

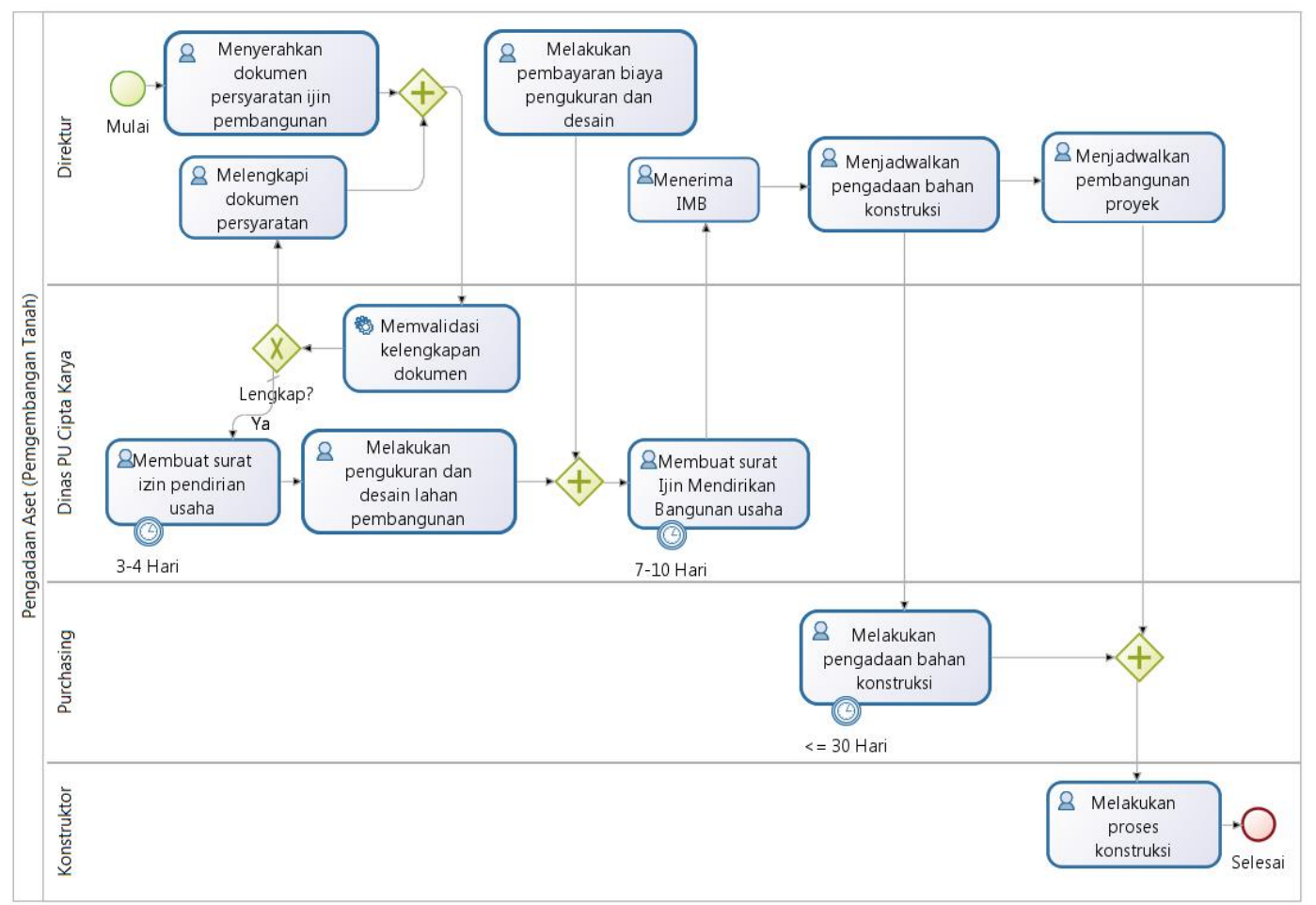

Gambar 8. Proses Pengadaan Aset Pengembangan Tanah dan Bangunan

tanah dan bangunan sampai aset tersebut disimpan di dalam gudang. Sedangkan pengadaan aset berupa tanah kosong atau yang akan dikembangkan dan bangunan akan dilaksanakan oleh direktur. Pengadaan aset tanah dan bangunan

\section{c) Pengoperasian aset}

Pada rencana proses penggunaan aset, aset yang akan digunakan hanya berasal dari gudang untuk mencegah kekeliruan pembaruan kartu stok dan kekeliruan pemindahan lokasi aset. Proses dapat dilihat pada Gambar 7, pengadaan aset pengembangan tanah dan bangunan dapat dilihat pada Gambar 8, dan pengadaan aset selain tanah dan bangunan dapat dilihat pada Gambar 9.

Penggunaan aset akan didokumentasikan dan akan dievaluasi dalam waktu berkala. Rencana proses pengoperasian aset dapat dilihat pada Gambar 10. 


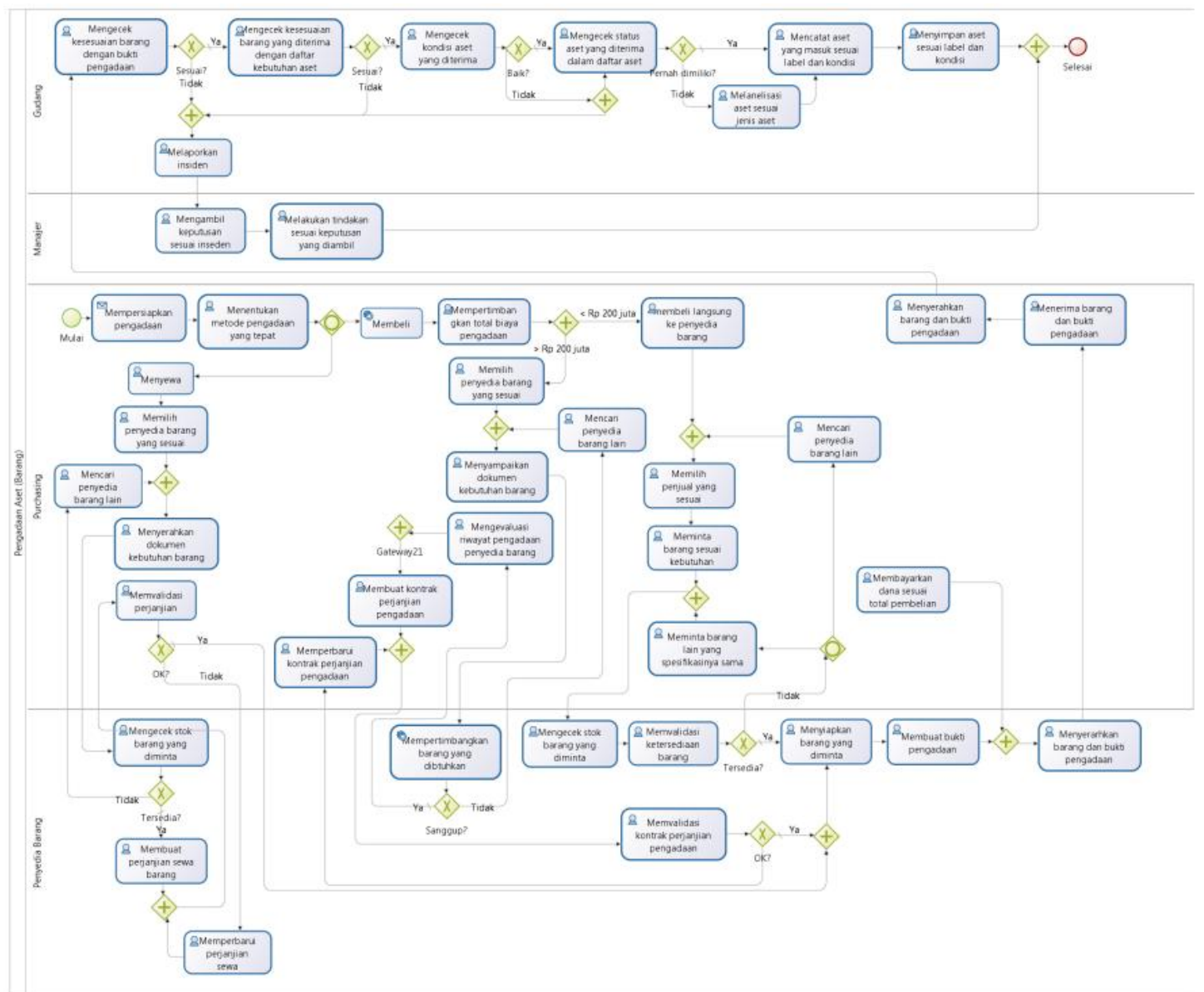

Gambar 9. Pengadaan Aset Barang Selain Tanah dan Bangunan

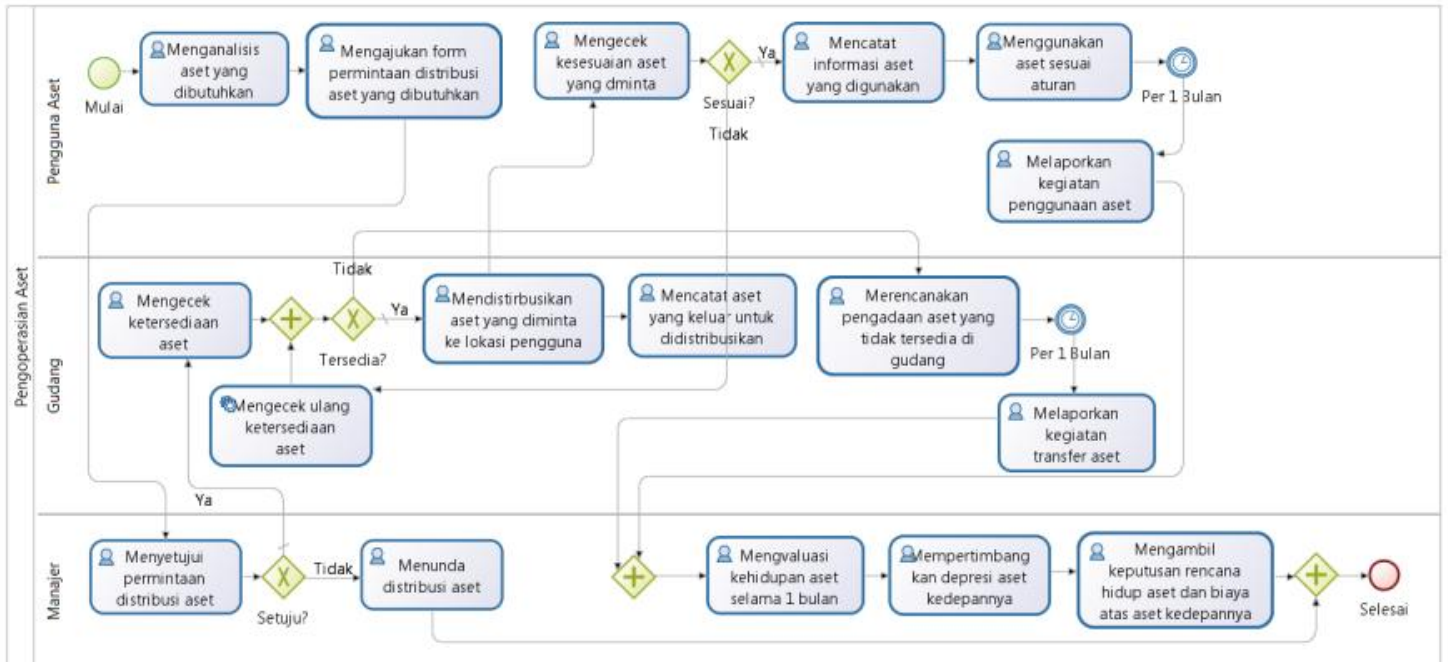

Gambar 10. Proses Pengoperasian Aset

d) Pemeliharaan aset,

Proses pemeliharaan aset perusahaan dilakukan oleh pemelihara dengan 2 cara yaitu ketika aset waktu pemeliharaan telah ditentukan secara berkala atau setelah ada laporan terkait kerusakan aset oleh pengguna aset. Rencana proses pemeliaraan aset dapat dilihat pada Gambar 11. e) Penghapusan aset,

Penghapusan aset dilakukan setelah manajer menerima laporan atas kerusakan parah aset perusahaan. Pada usulan proses penghapusan aset, saat manajer telah mendapatkan laporan tersebut, maka manajer akan mengambil keputusan untuk menghapus aset dari perusahaan. Rencana proses penghapusan aset dapat dilihat pada Gambar 12. 


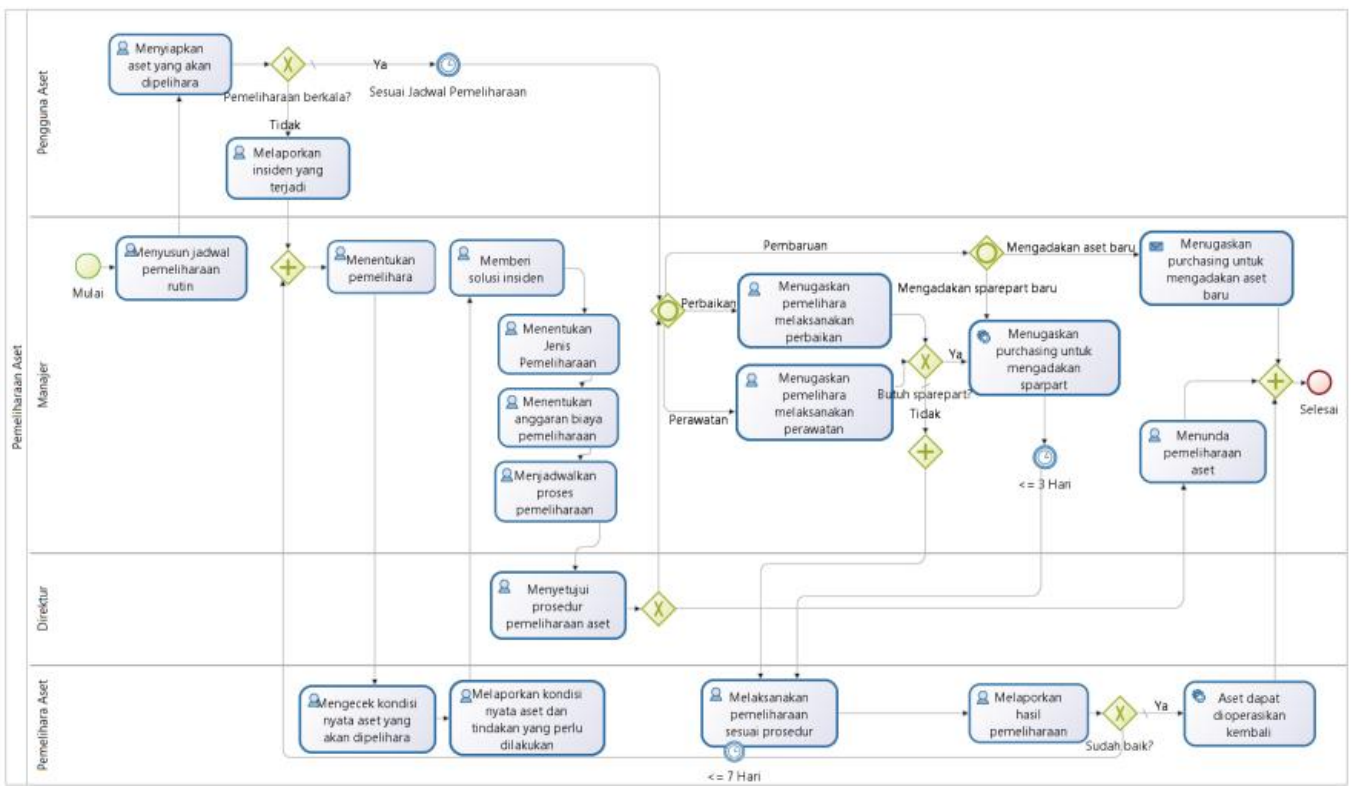

Gambar 11. Proses Pemeliharaan Aset

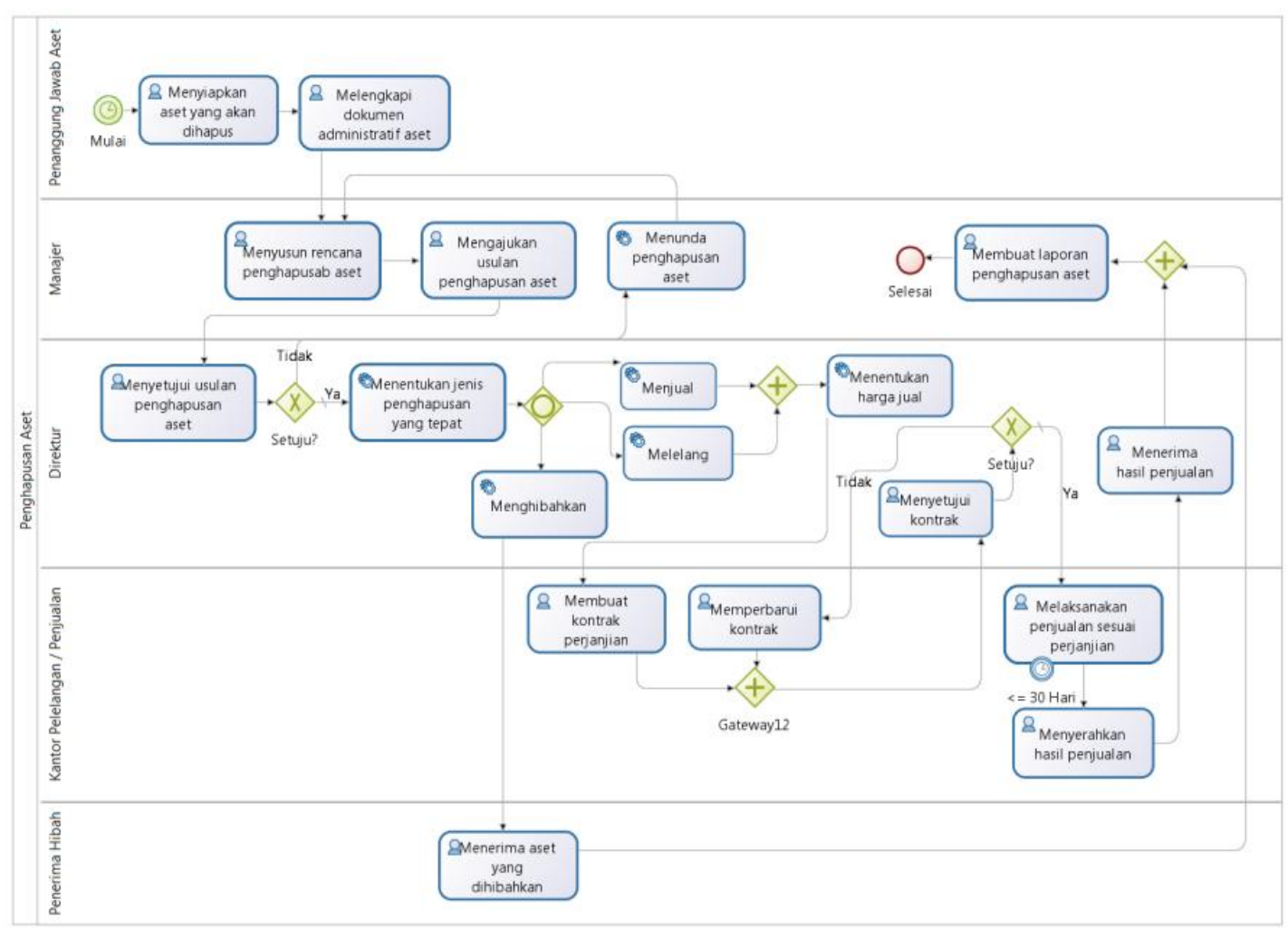

Gambar 12. Proses Penghapusan Aset

\section{Perencanaan Arsitektur}

Tahap perencanaan arsitektur dilakukan dengan 3 proses yaitu arsitektur data, arsitektur aplikasi, dan arsitektur teknologi. Proses perencanaan arsitektur ini menghasilkan cetak biru dari masing-masing arsitektur.

\section{1) Arsitektur Data}

Arsitektur data dilakukan dengan mempertimbangkan kebutuhan data dari tiap proses manajemen aset perusahaan. Setiap proses yang saling memiliki relasi menjadikan data dari seluruh proses juga dapat digunakan oleh proses mana saja. Kebutuhan data dari masing-masing proses dipetakan dalam Tabel 2. 
TABel 2. Kebutuhan Entitas Data dari Setiap Proses

\begin{tabular}{|c|c|c|c|c|c|c|c|c|c|c|c|c|c|c|c|c|c|}
\hline $\begin{array}{l}\text { PROSES } \\
\text { ENTITAS DATA }\end{array}$ & P1 & $\overline{\text { P2 }}$ & P3 & $\mathbf{P 4}$ & P5 & $\overline{\mathrm{P6}}$ & $\mathbf{P 7}$ & $\mathbf{P 8}$ & P9 & P10 & $\overline{P 11}$ & $\overline{P 12}$ & $\overline{P 13}$ & P14 & P15 & $\overline{P 16}$ & $\mathbf{P 1 7}$ \\
\hline Aset & $\mathrm{R}$ & & $\bar{R}$ & $\mathrm{R}$ & & $\mathrm{R}$ & $\bar{R}$ & $\mathrm{R}$ & $\mathrm{R}$ & $\mathrm{R}$ & $\mathrm{R}$ & $\mathrm{R}$ & $\mathrm{R}$ & $\mathrm{R}$ & $\mathrm{R}$ & $\mathrm{R}$ & $\mathrm{R}$ \\
\hline Informasi detail aset & & & & & & $\mathrm{R}$ & & & & $\mathrm{C} / \mathrm{U}$ & & & & & & & \\
\hline Unit organisasi & $\bar{R}$ & $\mathrm{R}$ & $\mathrm{R}$ & $\mathrm{R}$ & $\mathrm{R}$ & $\mathrm{R}$ & $\mathrm{R}$ & $\mathrm{R}$ & $\mathrm{R}$ & $\mathrm{R}$ & $\mathrm{R}$ & $\mathrm{R}$ & $\bar{R}$ & $\mathrm{R}$ & $\mathrm{R}$ & $\mathrm{R}$ & $\mathrm{R}$ \\
\hline Jabatan & $\mathrm{R}$ & $\mathrm{R}$ & $\bar{R}$ & $\mathrm{R}$ & $\mathrm{R}$ & $\mathrm{R}$ & $\bar{R}$ & $\mathrm{R}$ & $\bar{R}$ & $\bar{R}$ & $\bar{R}$ & $\bar{R}$ & $\overline{\mathrm{R}}$ & $\bar{R}$ & $\bar{R}$ & $\mathrm{R}$ & $\mathrm{R}$ \\
\hline Departemen & $\mathrm{R}$ & $\mathrm{R}$ & $\bar{R}$ & $\bar{R}$ & $\mathrm{R}$ & $\mathrm{R}$ & $\bar{R}$ & $\mathrm{R}$ & $\mathrm{R}$ & $\mathrm{R}$ & $\mathrm{R}$ & $\mathrm{R}$ & $\mathrm{R}$ & $\mathrm{R}$ & $\bar{R}$ & $\mathrm{R}$ & $\bar{R}$ \\
\hline Lokasi kerja & $\overline{\mathrm{R}}$ & $\mathrm{R}$ & $\overline{\mathrm{R}}$ & $\bar{R}$ & $\mathrm{R}$ & $\mathrm{R}$ & $\mathrm{R}$ & $\mathrm{R}$ & $\mathrm{R}$ & $\mathrm{R}$ & $\overline{\mathrm{R}}$ & $\bar{R}$ & $\overline{\mathrm{R}}$ & $\bar{R}$ & $\bar{R}$ & $\mathrm{R}$ & $\mathrm{R}$ \\
\hline Konstruktor & & & & & & & $\mathrm{C} / \mathrm{U}$ & & & & & & & & & & \\
\hline Vendor & & & & & & & & $\mathrm{C} / \mathrm{U}$ & & & & & & & & & \\
\hline Pemelihara aset & & & & & & & & & & & & & & & & $\mathrm{R}$ & \\
\hline Kebutuhan aset & $\mathrm{C} / \mathrm{U}$ & & 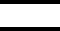 & & & & & & & & & & & & & & \\
\hline $\begin{array}{l}\text { Purchase requwst } \\
\end{array}$ & $\mathrm{C} / \mathrm{U}$ & $\mathrm{R} / \mathrm{U}$ & & & & & & & $\mathrm{R}$ & & & & & & & & \\
\hline Purchase request valid & & $\mathrm{C}$ & $\bar{R}$ & & & & & & & & & & & & & & \\
\hline Rencana pengadaan aset & & & $\mathrm{C} / \mathrm{U}$ & & & & $\mathrm{R}$ & $\mathrm{R}$ & & & & & & & & & \\
\hline Rencana pengoperasian aset & & & $\mathrm{C} / \mathrm{U}$ & & & & & & & & & & & $\mathrm{R}$ & 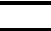 & & \\
\hline Rencana pemeliharaan aset & & & $\mathrm{C} / \mathrm{U}$ & & & & & & & & & & & & & & \\
\hline Rencana penghapusan aset & & & $\mathrm{C} / \mathrm{U}$ & & & & & & & & & & & & & & $\mathrm{R}$ \\
\hline Rencana kehidupan aset & & & $\mathrm{C} / \mathrm{U}$ & $\mathrm{R}$ & $\mathrm{R} / \mathrm{U}$ & & & & & & & & & & & & \\
\hline Biaya kehidupan aset & & & & $\mathrm{C} / \mathrm{U}$ & & & & & & & & & & & $\overline{\mathrm{R}}$ & & \\
\hline Rencana anggaran dana & & & & $\mathrm{C} / \mathrm{U}$ & $R / U$ & & $\mathrm{R}$ & $\mathrm{R}$ & & & & & & $\bar{R}$ & & & $\mathrm{R}$ \\
\hline $\begin{array}{l}\text { Detail biaya } \\
\end{array}$ & & & & & & & $\mathrm{C} / \mathrm{U}$ & $\mathrm{C} / \mathrm{U}$ & & & & & & $\mathrm{C} / \mathrm{U}$ & & $\mathrm{C} / \mathrm{U}$ & $\mathrm{C} / \mathrm{U}$ \\
\hline $\begin{array}{l}\text { Rencana kehidupan dan } \\
\text { anggaran dana yang telah } \\
\text { disetujui }\end{array}$ & & & & & $\mathrm{C}$ & & & & & & & & & & & & \\
\hline Pengadaan aset & & & & & & & $\mathrm{C} / \mathrm{U}$ & $\mathrm{C} / \mathrm{U}$ & & & & & & & & & \\
\hline Bukti pengadaan aset & & & & & & & $\mathrm{C}$ & $\mathrm{C}$ & $\mathrm{R}$ & & & & & & & & \\
\hline Penerimaan aset & & & & & & & & & $\mathrm{C} / \mathrm{U}$ & & & & & & & & \\
\hline Kartu stok & & & & & & & & & $\mathrm{U}$ & & & & $\mathrm{U}$ & & & & \\
\hline Penyimpanan aset & & & & & & & & & & & $\mathrm{C} / \mathrm{U}$ & & & & & & \\
\hline Insiden & & & & & & & & & & & & $\bar{R}$ & & & & & \\
\hline Pelaporan insiden & & & & & & & & & & & & $\mathrm{C} / \mathrm{U}$ & & & & & \\
\hline $\begin{array}{l}\text { Keputusan penindakan } \\
\text { insiden }\end{array}$ & & & & & & & & & & & & $\mathrm{C}$ & & & & & \\
\hline Permintaan distribusi aset & & & & & & & & & & & & & $\mathrm{C} / \mathrm{U}$ & & & & \\
\hline Distribusi aset & & & & & & & & & & & & & $\mathrm{C} / \mathrm{U}$ & & & & \\
\hline $\begin{array}{l}\text { Pengoperasian aset } \\
\end{array}$ & & & & & & & & & & & & & & $\mathrm{C} / \mathrm{U}$ & & & \\
\hline Audit aset & & & & & & & & & & & & & & & $\mathrm{C} / \mathrm{U}$ & & \\
\hline $\begin{array}{l}\text { Kaputusan kelanjutan hidup } \\
\text { aset }\end{array}$ & & & & & & & & & & & & & & & $\mathrm{C} / \mathrm{U}$ & & \\
\hline Pemeliharaan aset & & & & & & & & & & & & & & & & $\mathrm{C} / \mathrm{U}$ & \\
\hline Usulan penghapusan aset & & & & & & & & & & & & & & & & & $\mathrm{C} / \mathrm{U}$ \\
\hline Penghapusan aset & & & & & & & & & & & & & & & & & \\
\hline
\end{tabular}

Keterangan:

$\begin{array}{ll}\text { P1 } & \text { : Mengelola data purchase request } \\ \text { P2 } & \text { : Validasi daftar purchase request } \\ \text { P3 } & \text { : Mengelola rencana kehidupan aset } \\ \text { P4 } & \text { : Mengelola rencana anggaran life-cycle cost aset } \\ \text { P5 } & \text { : Validasi rencana kehidupan dan anggaran life-cyle cost asset } \\ \text { P6 } & \text { : Melihat informasi detail aset } \\ \text { P7 } & \text { : Pengelolaan pembangunan proyek } \\ \text { P8 } & \text { : Pengelolaan pengadaan aset } \\ \text { P9 } & \text { : Mengelola data penerimaan asset } \\ \text { P10 } & \text { : Mengelola informasi asset } \\ \text { P11 } & \text { : Mengelola penyimpanan asset }\end{array}$

\section{2) Arsitektur Aplikasi}

Arsitektur aplikasi yang direncanakan merupakan daftar kandidat-kandidat aplikasi yang kemungkinan besar dibutuhkan oleh pihak perusahaan dalam menjalankan proses manajemen aset. Kandidat aplikasi yang direncanakan termasuk aplikasi yang mendukung proses perencanaan aset, pengadaan aset, pengoperasian aset, pemeliharaan aset, dan penghapusan aset yang terintegrasi dengan satu basis data terpusat.

Perencanaan arsitektur aplikasi dilakukan sesuai dengan kebutuhan data dari setiap proses bisnis pada Tabel 1. Kandidat aplikasi ditentukan pada proses bisnis dengan kebutuhan data terbanyak. Kandidat aplikasi dari proses manajemen aset dapat dilihat pada Tabel 3.

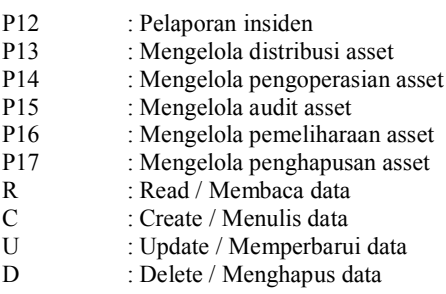

Tabel 3. Kandidat Aplikasi Proses Manajemen Aset

\begin{tabular}{|c|c|c|c|}
\hline No. & Proses & Kandidat Aplikasi & Keterangan \\
\hline 1 & \multirow{2}{*}{$\begin{array}{l}\text { Perencanaan } \\
\text { Aset }\end{array}$} & $\begin{array}{c}\text { Sistem manajemen } \\
\text { perencanaan aset }\end{array}$ & $\begin{array}{c}\text { Pengembangan } \\
\text { baru }\end{array}$ \\
\hline 2 & & $\begin{array}{l}\text { Aplikasi barcode } \\
\text { reader }\end{array}$ & $\begin{array}{c}\text { Pengembangan } \\
\text { baru }\end{array}$ \\
\hline 3 & \multirow{3}{*}{ Pengadaan Aset } & $\begin{array}{c}\text { Sistem pengelolaan } \\
\text { pengadaan aset }\end{array}$ & $\begin{array}{c}\text { Pengembangan } \\
\text { baru }\end{array}$ \\
\hline 4 & & $\begin{array}{l}\text { Sistem manajemen } \\
\text { gudang }\end{array}$ & $\begin{array}{c}\text { Pengembangan } \\
\text { baru }\end{array}$ \\
\hline 5 & & $\begin{array}{l}\text { Aplikasi pelaporan } \\
\text { insiden }\end{array}$ & $\begin{array}{c}\text { Pengembangan } \\
\text { baru }\end{array}$ \\
\hline 6 & \multirow{3}{*}{$\begin{array}{l}\text { Pwngoperasian } \\
\text { Aset }\end{array}$} & $\begin{array}{c}\text { Sistem manajemen } \\
\text { penggunaan aset }\end{array}$ & $\begin{array}{c}\text { Pengembangan } \\
\text { baru }\end{array}$ \\
\hline 7 & & $\begin{array}{l}\text { Sistem manajemen } \\
\text { gudang }\end{array}$ & $\begin{array}{c}\text { Pengembangan } \\
\text { baru }\end{array}$ \\
\hline 8 & & $\begin{array}{c}\text { Sistem pengelolaan } \\
\text { audit }\end{array}$ & $\begin{array}{c}\text { Pengembangan } \\
\text { baru }\end{array}$ \\
\hline 9 & \multirow{2}{*}{$\begin{array}{l}\text { Pemeliharaan } \\
\text { Aset }\end{array}$} & $\begin{array}{c}\text { Sistem manajemen } \\
\text { pemeliharaan aset }\end{array}$ & $\begin{array}{c}\text { Pengembangan } \\
\text { baru }\end{array}$ \\
\hline 10 & & $\begin{array}{l}\text { Aplikasi pelaporan } \\
\text { insiden }\end{array}$ & $\begin{array}{c}\text { Pengembangan } \\
\text { baru }\end{array}$ \\
\hline 11 & $\begin{array}{l}\text { Penghapusan } \\
\text { Aset }\end{array}$ & $\begin{array}{c}\text { Sistem manajemen } \\
\text { penghapusan aset }\end{array}$ & $\begin{array}{c}\text { Pengembangan } \\
\text { baru }\end{array}$ \\
\hline
\end{tabular}

Perencanaan Arsitektur Perusahaan untuk Pengelolaan Aset di PT. Musdalifah Group 


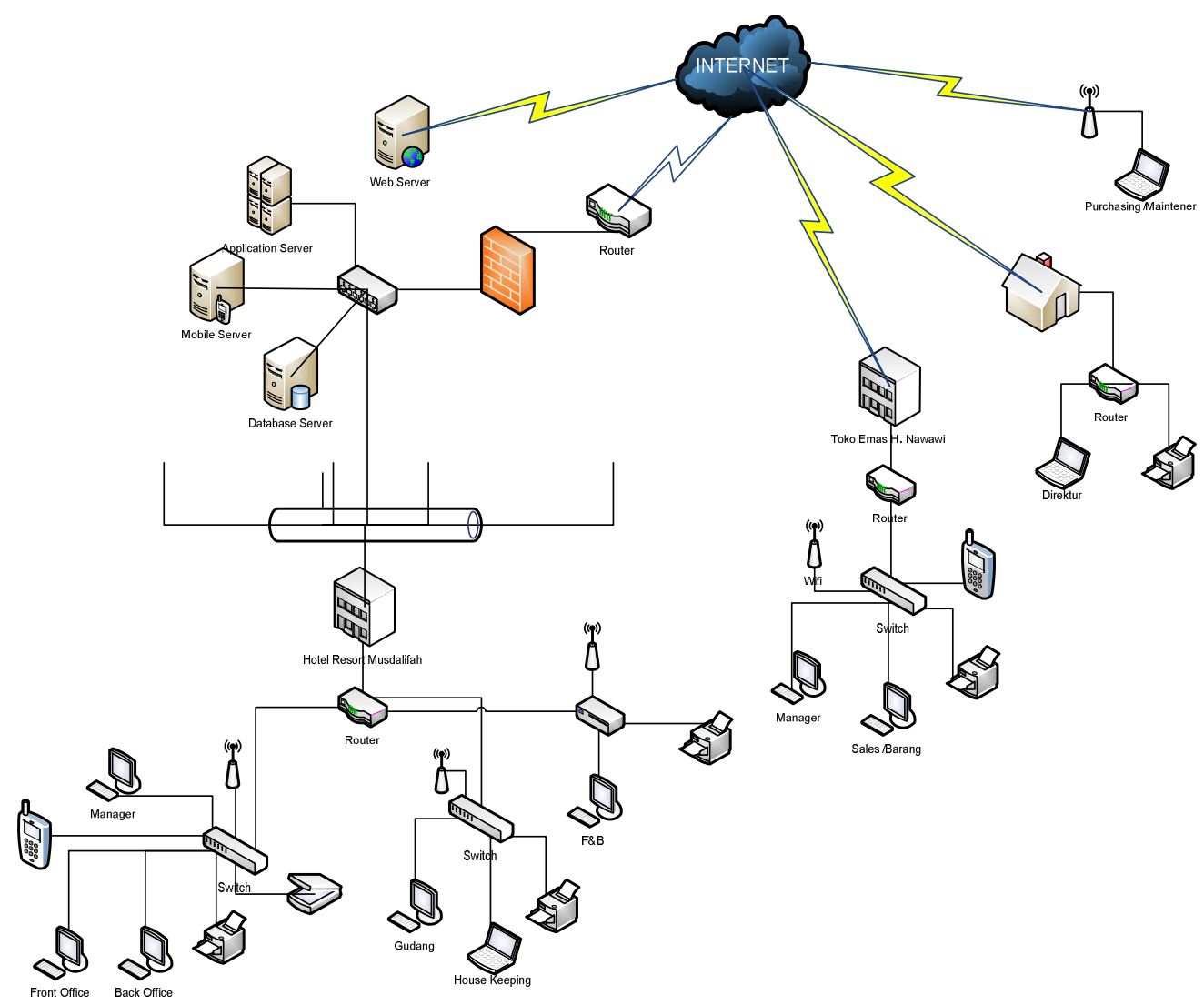

Gambar 13. Arsitektur Jaringan Komputer

Tabel 4. Kandidat Teknologi Manajemen Aset

\begin{tabular}{|c|c|c|c|c|}
\hline No. & Kandidat Aplikasi & Pengguna & Perangkat Keras & Platform Aplikasi \\
\hline 1 & Sistem manajemen perencanaan aset & $\begin{array}{c}\text { Direktur } \\
\text { Front Office } \\
\text { Back Office } \\
\text { House Keeping } \\
\text { Gudang } \\
\text { Food \& Baverage } \\
\text { Sales \& Stok Barang } \\
\text { Purchasing } \\
\text { Manager }\end{array}$ & $\begin{array}{c}\text { PC } \\
\text { Laptop }\end{array}$ & 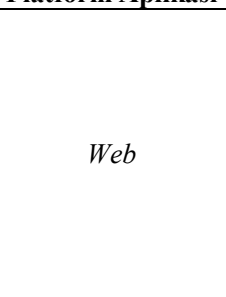 \\
\hline 2 & Aplikasi barcode reader & Manager & Smart Phone & Mobile \\
\hline 3 & Sistem manajemen pengadaan aset & $\begin{array}{c}\text { Direktur } \\
\text { Purchasing }\end{array}$ & Laptop & $W e b$ \\
\hline 4 & Sistem manajemen gudang & Gudang & $\mathrm{PC}$ & Desktop \\
\hline 5 & Aplikasi pelaporan insiden & $\begin{array}{c}\text { Direktur } \\
\text { Front Office } \\
\text { Back Office } \\
\text { House Keeping } \\
\text { Gudang } \\
\text { Food \& Baverage } \\
\text { Sales \& Stok Barang } \\
\text { Purchasing } \\
\end{array}$ & $\begin{array}{c}\text { PC } \\
\text { Laptop }\end{array}$ & $W e b$ \\
\hline 6 & Sistem manajemen penggunaan aset & $\begin{array}{c}\text { Direktur } \\
\text { Front Office } \\
\text { Back Office } \\
\text { House Keeping } \\
\text { Gudang } \\
\text { Food \& Baverage } \\
\text { Sales \& Stok Barang } \\
\text { Purchasing } \\
\end{array}$ & $\begin{array}{c}\text { PC } \\
\text { Laptop }\end{array}$ & $W e b$ \\
\hline 7 & Sistem manajemen audit aset & Manager & $\mathrm{PC}$ & Desktop \\
\hline 8 & Sistem manajemen pemeliharaan aset & $\begin{array}{l}\text { Direktur } \\
\text { Manager }\end{array}$ & $\begin{array}{c}\text { PC } \\
\text { Laptop }\end{array}$ & Web \\
\hline 9 & Sistem manajemen penghapusan aset & $\begin{array}{c}\text { Direktur } \\
\text { Manager } \\
\text { Penanggung jawab aset }\end{array}$ & $\begin{array}{c}\text { PC } \\
\text { Laptop }\end{array}$ & Web \\
\hline
\end{tabular}

Enterprise Architecture Planning for Asset Management in PT. Musdalifah Group using Zachman Framework 
TABel 5. Urutan Prioritas Pengembangan APLIKASI

\begin{tabular}{|c|c|c|c|c|c|}
\hline Urutan Prioritas & Kandidat Aplikasi & Perangkat Keras & Platform Aplikasi & Prioritas & Urgensi \\
\hline 1 & $\begin{array}{c}\text { Sistem manajemen } \\
\text { perencanaan aset }\end{array}$ & $\begin{array}{c}\text { PC } \\
\text { Laptop }\end{array}$ & Web & Tinggi & Tinggi \\
\hline 8 & Aplikasi barcode reader & Smart Phone & Mobile & Sedang & Rendah \\
\hline 2 & Sistem manajemen gudang & $\mathrm{PC}$ & Desktop & Sedang & Tinggi \\
\hline 9 & Aplikasi pelaporan insiden & $\begin{array}{c}\text { PC } \\
\text { Laptop }\end{array}$ & $W e b$ & Rendah & Sedang \\
\hline 5 & Sistem manajemen audit aset & $\mathrm{PC}$ & Desktop & Sedang & Sedang \\
\hline 6 & $\begin{array}{c}\text { Sistem manajemen } \\
\text { pemeliharaan aset }\end{array}$ & $\begin{array}{c}\text { PC } \\
\text { Laptop }\end{array}$ & $W e b$ & Sedang & Sedang \\
\hline 7 & $\begin{array}{c}\text { Sistem manajemen } \\
\text { penghapusan aset }\end{array}$ & $\begin{array}{c}\text { PC } \\
\text { Laptop }\end{array}$ & $W e b$ & Sedang & Sedang \\
\hline
\end{tabular}

TABEL 6. PERTIMBANGAN CETAK BIRU DENGAN PENDEKATAN KELAYAKAN TEKNIS, EKONOMIS, DAN WAKTU

\begin{tabular}{|c|l|l|}
\hline Rencana Arsitektur & \multicolumn{1}{|c|}{ Dampak Positif } & \multicolumn{1}{|c|}{ Dampak Negatif } \\
\hline Proses bisnis & $\begin{array}{l}\text { Prosedur yang telah direncanakan dapat } \\
\text { meminimalisair resiko kerugian yang terjadi saat } \\
\text { proses manajemen aset berlangsung }\end{array}$ & $\begin{array}{l}\text { Membutuhkan waktu yang lama untuk beradaptasi } \\
\text { dengan proses bisnis manajemen aset yang } \\
\text { direncanakan karena unit organisasi sudah terbiasa } \\
\text { dengan sistem manual }\end{array}$ \\
\hline Data & $\begin{array}{l}\text { Dapat mengintegerasikan data lintas platform dan } \\
\text { aplikasi dengan jarak dekat atau jauh dengan waktu } \\
\text { singkat }\end{array}$ & $\begin{array}{l}\text { Membutuhkan biaya besar untuk membangun basis } \\
\text { data yang terintegerasi }\end{array}$ \\
\hline Aplikasi & $\begin{array}{l}\text { Pelaksanaan proses manajemen aset dapat lebih } \\
\text { efektif dan efisien dengan aplikasi yang mudah } \\
\text { digunakan dan paperless }\end{array}$ & $\begin{array}{l}\text { Dibutuhkan waktu yang lama untuk sampai pada } \\
\text { tahap pengimplementasian aplikasi karena aplikasi } \\
\text { masih harus dibangun dan pengguna harus di } \\
\text { training secara berkala (phased })\end{array}$ \\
\hline Teknologi & $\begin{array}{l}\text { Teknologi yang terintegerasi sesuai dengan } \\
\text { jaringan komputer yang direncanakan menjadikan } \\
\text { proses manajemen aset lebih efektif dan efisien }\end{array}$ & $\begin{array}{l}\text { Dibutuhkan waktu yang lama untuk membangun } \\
\text { jaringan kompueter yang mengintegerasikan banyak } \\
\text { sistem di beda lokasi dengan biaya yang sangat } \\
\text { besar untuk pengadaan komponen teknologinya }\end{array}$ \\
\hline
\end{tabular}

\section{3) Arsitektur Teknologi}

Arsitektur toknologi direcanakan dengan mengacu pada kandidat aplikasi dan unit organisasi perusahaan yang berlaku sebagai pengguna dari aplikasi itu sendiri. Kandidat teknologi manajemen aset yang telah direncanakana dapat dilihat pada Tabel 4 .

Dari penentuan prinsip teknologi dapat digambarkan arsitektur jaringan komputer seperti pada Gambar 13.

\section{E. Rencana implementasi}

Fase rencana implementasi pada penelitian ini dilakukan dengan tahapan penentuan urutan prioritas pengembangan aplikasi, pembuatan estimasi pelaksanaan implementasi, dan pembuatan kesimpulan penelitian berdasarkan evaluasi terhadap pihak perusahaan.

Penentuan urutan prioritas pengembangan aplikasi dilakukan dengan mempertimbangkan 2 aspek, yaitu tingkat prioritas dan tingakt urgensi. Tingkat prioritas dari aplikasi ditentukan berdasarkan tinggi kebutuhan dan kemampuan dari pihak perusahaan terhadap pengimplementasian dari aplikasi itu sendiri. Penentuan prioritas ini dilakukan dengan pengisian kuesioner oleh pihak top level management perusahaan terkait tinggi kebutuhan pihak perusahaan terhadap sistem yang telah direncanakan. Sedangkan tingkat urgensi merupakan hasil pemikiran peneliti terkait tinggi kontribusi sistem yang telah direncanakan bagi perusahaan. Pengurutan prioritas aplikasi dapat dilihat pada Tabel 5 .

Perencanaan estimasi waktu pelaksanaan implementasi sistem didasarkan dari estimasi waktu yang dibutuhkan mulai mempersiapkan komponen-komponen yang dibutuhkan untuk menjalankan sistem secara keseluruhan sampai sistem siap untuk diimplementasikan. Rencana proses migrasi sistem ini dapat dilihat pada Gambar 14.

Penarikan kesimpulan dari rencana implementasi dilakukan dengan evaluasi hasil penelitian kepada pihak perusahaan. Pertimbangan terhadap pendekatan kelayakan terkait evaluasi hasil cetak biru arsitektur yang telah direncanakan dapat dilihat pada Tabel 6 .

Evaluasi cetak biru dilakukan dengan wawancara evaluasi rencana implementasi kepada bagian top management PT. Musdalifah Group. Hasil dari evaluasi ini pernyataan dari pihak perusahaan bahwa secara keseluruhan cetak biru arsitektur yang telah direncanakan dapat berguna dan berpengaruh baik terhadap proses manajemen aset perusahaan yang saat ini masih belum terdokumentasi dengan baik, tetapi hal tersebut baru akan terealisasi beberapa tahun kedepan. 
Langkah yang diambil oleh pihak perusahaan

enterprise adalah akan segera menguji coba terkait implementasi cetak biru arsitektur

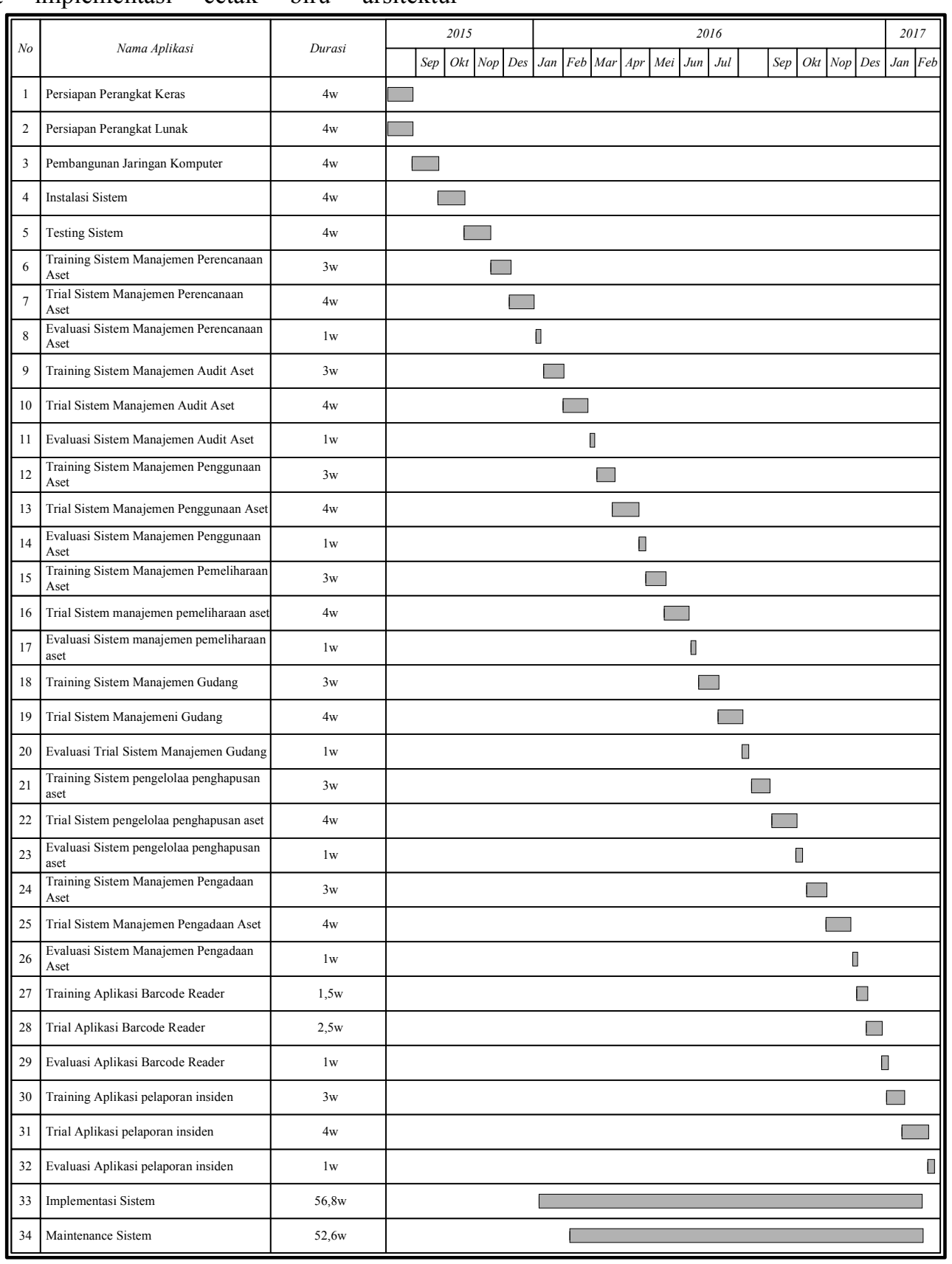

Gambar 14. Rencana Migrasi Sistem

proses bisnis dan arsitektur data yang telah direncanakan dengan pengaplikasian data berupa dokumen kertas. Apabila dalam kegiatan uji coba proses bisnis tersebut dirasa dapat beradaptasi cepat dengan kondisi perusahaan, pihak top management akan mulai merencanakan pengadaan komponen lain agar cetak biru dapat diimplementasikan secara keseluruhan.

\section{KESIMPULAN}

Penelitian ini menghasilkan cetak biru arsitektur data, aplikasi, dan teknologi yang dapat dijadikan sebagai pedoman dalam pembangunan sistem informasi dan teknologi informasi yang mendukung proses manajemen aset PT. Musdalifah Group.

Pada tahap pengujian sistem dengan pendekatan kelayakan terhadap kualitas, biaya, dan waktu dapat dinyatakan cetak biru arsitektur dapat diterima dan layak secara kualitas karena dapat memperbaiki proses manajemen aset di PT. Musdalifah Group. Namun, pengimplementasian cetak biru membutuhkan waktu yang cukup lama dan membutuhkan biaya yang besar untuk pengadaan komponen yang masih belum dimiliki dan pembangunan jaringan komputer terintegrasi yang baru. 
Dari hasil evaluasi cetak biru enterprise dan rencana implementasi, pihak PT. Musdalifah Group akan mencoba mengimplementasi cetak biru proses bisnis dan arsitektur data dengan memanfaatkan dokumen kertas. Setelah dirasa dapat beradaptasi dengan kondisi perusahaan, akan dilanjutkan dengan mengimplementasi kandidat aplikasi berbasi web dan mobile. Setelah itu, perusahaan akan merencanakan pengadaan komponen arsitektur teknologi dan pengimplementasian secara keseluruhan.

\section{DAFTAR PUSTAKA}

Brown, K., Laue, M., Keast, r., Mahmood, N., Wiewiora, A., \& Montagomery-Hribar, J. (2012). Pedoman Sistem Terpadu Pengelolaan Aset yang Strategis. Brisbane, Australia: Hanna Murphy.

Hidayat, M. (2012). Manajemen aset: Privat dan Publik. Yogyakarta: LaksBang PRESSindo.

Mahasanti, E. K. (2010). Perencanaan Dan Perancangan Arsitektur E-University Menggunakan Zachman Framework Pada Domain Manajemen Asset. Tugas Akhir,
Institut Teknologi Telkom, Program Studi Sistem Informasi.

Minoli, D. (2008). Enterprise Architecture A to Z: Frameworks, Business Process Modeling, SOA, Infrastructure Technology. Boca Raton: Taylor \& Francis Group.

Spewak, S. H., \& Hill, S. C. (1992). Enterprise Architecture Planning, Developing a Blueprint for Data, Applications, and Technology. John Wiley \& Sons,Inc.

Suhairi. (2013). Perancangan Sistem Informasi Manajemen Aset: Studi Kasus PT. Ciptakridatama. Thesis, Universitas Gunadarma, Magister Sistem Informasi.

Tyas, T. S., \& Tarmuji, A. (2013). Peracangan Enterprise Architecture Planning (EAP) Pada Proses Manajemen Aset Dengan Zachman Framework: Studi Kasus Divisi Manajemen Fasilitas PT. XYZ. Jurnal Sarjana Teknik Informatika, 1 No.1, 97-110.

Zachman, J. A. (2003). Excerpted from The Zachman Framework: A Primer for Enterprise Engineerind and Manufacturing. zachman.com: Zachman International. 